\title{
ANIMAL WELFARE: CHILDREN'S PLURAL DISCOURSES IN CONTEXTS OF EARLY CHILDHOOD EDUCATION
}

\author{
C. Tomás ${ }^{1}$, M. Botelho' ${ }^{2}$ A. Almeida ${ }^{1}$ \\ ${ }^{1}$ Instituto Politécnico de Lisboa (IPL)/CICS.NOVA (PORTUGAL) \\ ${ }^{2}$ Colégio Piloto Diese e Movimento da Escola Moderna (PORTUGAL)
}

\begin{abstract}
The present work is focused on the presentation of some results of a project developed about the social representations of children on animal welfare and animal rights (e.g., cultural demonstrations with animals, exhibition of animals in captivity, production and consumption of products of animal origin, treatment of pets and farm animals). They are preliminary results within the scope of a broader project "ANIMALIS - Animal welfare in pre-service kindergarten and primary school teachers' education. Using the Sociology of Childhood, Childhood Pedagogy, Environmental Education and Human-animal Studies, the present work aims to analyse children's discourses associated with factors which can limit animal welfare and their rights and also to identify possibilities of educational intervention compatible with the inclusion of animals and their rights in pedagogical practices. These discourses started from the analysis and discussion of situations involving different animal uses present in the book of Patrick George "Animal Rescue" published by 2015. The methodological approach is based on a qualitative matrix with the adoption of data collection and analysis methodologies congruent with the object under study and with the epistemological assumptions of the sociological research with children: ethnographic observation, image collection, analysis of drawings, documentary analysis and focused discussion groups (book as an inducer of the discussion). The selection obeyed the criteria of identification of specificity, interest and feasibility of the research. The participants were four groups of children, between 2 and 5 years old, from three Kindergarten rooms (25 children each room) and one nursery room (12 children) of a private socio-educational organization in the city of Lisbon. The situations designed around animals, promoted by four educators with extensive professional experience, allowed to identify certain practices developed with animals (i) as problematic for children (e.g. abandonment and neglect of animals, sale of animals in stores, use of animal fur to make clothing and footwear) and (ii) as necessary (e.g., the need to invest more in promoting animal and nature rights, to reflect on the role of pets in their lives, and to develop projects to learn more about particular animals or situations involving them). The conflict between individual and group visions is a theme to be highlighted from the analysis of data as well as the fact that children in the nursery room reveal more blurred boundaries between the human and non-human worlds.
\end{abstract}

Keywords: Children, Animal Welfare, Animal's Rights, Early Childhood Education.

\section{INTRODUCTION}

Animal welfare is nowadays a complex issue, generating a great political, legal and academic interest, which can be mainly associated with Environmental Education (EA). In education, it is seen as posing immense challenges, placing professionals of education in face of the need to respond to these challenges. The growth of political parties in the world, including animal rights and their protection in their programs and action, is an example of how the present issue is in the international agenda. For instance, in Portugal, the publication of the Law n. ${ }^{\circ} / 2017$ of March $3^{\text {rd }}$, establishes a legal status of animals, recognizing their nature as living beings with sensitivity, (Diário da República 2017), amending the Civil Code, approved by Decree-Law No. 47344 of 25 of November 1966 of the Civil Procedure Code.

The dominant view on animal welfare issues has been centered on the defense of the sustainable development paradigm, mainly focused on the sustainable use of resources, in a logic of maintaining the western lifestyle. In its view the dimension of caring for the environment has appeared (almost) always dissociated from the relationship between humans and other animals ([1] Cole \& Stewart, 2014) or between human and non-human worlds ([2] Charles \& Davies, 2008; [3] Policarpo, Monteiro, Truninger, Almeida, \& Rodrigues, 2018). On the other hand, the place that animals occupy in 
legitimizing discourses of social relations with children is little recognized ([4] Ascione, 2005; [5] Tipper, 2011).

On the contrary, an anti-hegemonic view is based on the defense of other forms of human / social organization and of relationship with the environment and the other species.

There are very few studies in Portugal that consider the relationship between children and animals, especially involving the youngest ones. This situation gives a social and academic relevance to the project "ANIMALIS - Animal welfare in pre-service kindergarten and primary school teachers' education", which has as its aims to study this relationship. This paper aims to present some data resulting from the analysis of the social representations of young children about different animal welfare issues (eg, cultural manifestations with animals, exhibition of captive animals, production and consumption of animal products, treatment of pets and domestic animals and animal rights).

The literature for childhood has been focused primarily on two fields of approach to animal issues: the understanding and description of general types of diversity in the animal world and the proposed use of animals in the development of social and cognitive skills. Thus, theoretical perspectives to explain children's contemporary experiences with animals have been dominated by psychology and by science. Also, the studies developed have mostly involved children over 6 years old and attending primary education. Nevertheless, the interactions between animals and children have been studied, especially from multidisciplinary fields as Human-Animal Studies and Child Studies.

\section{METHODOLOGY}

Considering that children have multiple and heterogeneous forms of expression - polyvocity -, the Child Studies, as a transdisciplinary field, have argued that it is necessary to recognize and value the social interpretations made by children and that a set of appropriate methodologies needs to be convened to pick up their voices. Therefore, the methodological approach is based on a qualitative matrix with the adoption of methodologies for data collection and analysis congruent with the object under study and with the epistemological assumptions of sociological research with children: ethnographic observation, image collection, analysis of drawings, document analysis and focused discussion groups. These discourses started from the analysis and discussion of situations involving different animal uses present in the book of [6] Patrick George "Animal Rescue" published in 2015.

Thus, the exploratory study presented addresses a crucial issue focused on animal rights, which has not been studied in Portugal, at least from a multidisciplinary, comparative and child-centered perspective (up to 6 years old), rethinking the value and social meaning of their language in the social and cultural worlds that inhabit them as social actors.

The selection followed criteria to identify the specificity, interest and feasibility of the research. The situations analyzed around the animals involved four groups of children, between 2 and 5 years old three kindergarten rooms ( 25 children each room) and one nursery room (12 children) of a private socio-educational organization in the city of Lisbon, and were promoted by four kindergarten educators. The detailed information is shown in Table 1.

Table 1. Participants' sociodemographic characterization.

\begin{tabular}{|c|c|c|}
\hline & Educator & Children \\
\hline $\begin{array}{l}\text { Room A - } \\
\text { kindergarten }\end{array}$ & female; 32 years old; 9 years' service time) & $\begin{array}{c}25 \text { (3-5 years old; } 14 \text { girls and } 11 \\
\text { boys) }\end{array}$ \\
\hline $\begin{array}{l}\text { Room B - } \\
\text { kindergarten }\end{array}$ & female; 34 years old; 10 years' service time) & $\begin{array}{c}25 \text { (3-4 years old; } 14 \text { girls and } 11 \\
\text { boys) }\end{array}$ \\
\hline $\begin{array}{l}\text { Room } \mathrm{C}- \\
\text { kindergarten }\end{array}$ & female; 42 years old; 18 years' service time) & $\begin{array}{c}25 \text { (4-5 years old; } 11 \text { girls and } 14 \\
\text { boys) }\end{array}$ \\
\hline Room D - nursery & female; 36 years old; 14 years' service time) & 12 (2-3 years old; 5 girls and 7 boys) \\
\hline
\end{tabular}

Books are important pedagogical tools for analyzing animal welfare and rights issues in early childhood education (kindergarten and nursery) as well as to understand how children and adults interpret these cultural products and include them in their worldviews, relationships and actions. Thus, after reading, viewing and manipulating the books by both educators and children, an interview was 
conducted in the focus group modality. Children's dialogues were presented anonymously and only the first letter of their name is referred. The children also made drawings and panels about a topic they wanted to talk about.

It should be noted that the book consists of a set of images about different animal uses, as an element for discussion ([6] George, 2015). The animals included in different uses (contexts) are: the elephant, the elk, the turtle, the chicken, the crocodile, the bear, the shark, the fox, the orca and the dog. The book includes illustrations with interactive transparent pages which help to build different perspectives for the same situation involving a certain animal: an instrumental view centered on human being and a biocentric view, centered on animal welfare and rights. This approach can help shaping up identities and (un)veiling certain representations.

\section{RESULTS}

\subsection{From the book images to animal welfare and rights discussion}

For the purpose of the analysis, we considered for this text a set of criteria that guided the choice of two dimensions of analysis in relation to the most exemplary representations that children presented in their discourses and drawings about the animals: (i) emotions towards animals; and (ii) animal rights. In this latter dimension, the zoo and the circus issues assumed special relevance because of the source of tension and diversity of opinions they caused among the children.

Thrilled representations or emotions of the children when talking about animals. What children say:

- The dog is happier to be home with his friend than to be in the dustbin (M.).

- The dog is not happy because it is in the dustbin. He stays with his owner (J.).

The educator asks $P$. to share his weekend experience with animals in an association.

- I go for a walk with them (dogs). We go to a park. I have cats and goldfish (P.).

- There is a place that is like this... one puts the money in there and can keep the dog for himself (referring to a pet store) (A.)

- There they are trapped - she says a little outraged (C).

- Yes....(P.).

- But we can own them - he says (A.). (Focus group, Room A, jan. 2019)

- When animals are in places they don't like or where they don't belong, they feel bad (L.).

- They are happier if they are not in cages (L.) (Focus group and pictures, Room C, jan. 2019)

The discussion shows us how children associate a set of emotions with the situations included in the book, in this particular case, in relation to a dog. In fact, the affective component of emotion assumes particular importance in this research, as a fundamental dimension in the constitution and rationalization of children's actions in their relationship with animals. This evocation of emotions that is present in children's discourses, as an indeclinable component of individual and collective action, has fostered a discussion about the role they can play when facing injustices committed against animals, of which the following statements are good examples:

- We can help the animals (D.), - To be happy (L.) (Room C), -We must treat the animals well (H.) (Room B).

It is curious, but not by chance, that the child rights have taken a particular role in the research. Here it is what children say about them.

- What did you find out in the other day with the book? - asks the educator.

The children all started talking at the same time.

- What do they have like us? - asks the educator.

- Rights. (Room B)

A few examples of children's drawings about animal rights are shown in Figures 1, 2 and 3. 

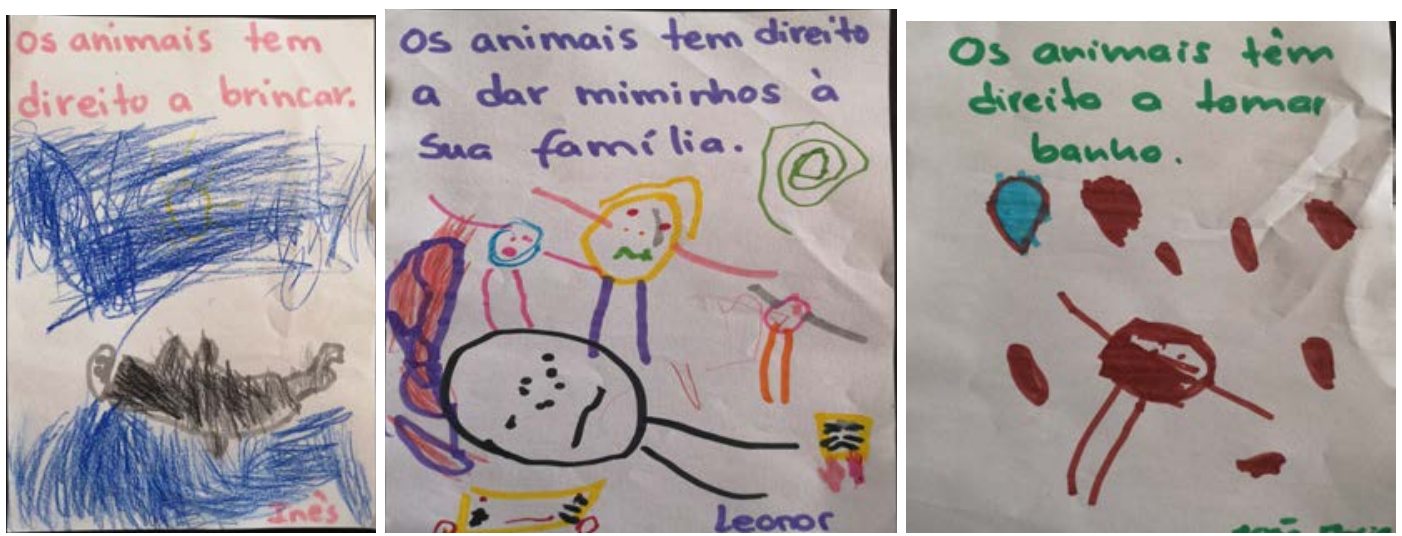

Figures 1, 2 and 3. Children's drawings about animal rights. From left to right: Os animais têm direito a brincar (animals have the right to play); Os animais têm direito a dar miminhos à sua familia (animals have the right to cuddle their family); Os animais têm direito a tomar banho (animals have the right to bathe) (Room B).

The educator shows the book again and goes through the pages.

- They [the animals] had no home. Their friends would be sad - says E.

- It is in a net [the turtle] but it would be better in the sea - says V.

- It is crocodile boots, he says.

- They [crocodiles] eat the boots. They are happy in the sea - says G.

- The bear is in a prison - says L.

- In the zoo they are happy - says L.

Faced with the image of an orca in the book, another debate arises around whether it is an orca or a whale. The educator tells them that it is an orca and the zoo theme is revived.

There is a big discussion about the animals in the zoo. Some children say it is a good place for animals but others don't agree.

- Dolphins like (to be in the zoo) because they have enough water and are happy - says L.

- I wanted to say something - says E, putting his arm in the air. -It is a seal and they should stay in the sea.

- In the zoo, there is a pool for dolphins, says M.

- When I went to the Zoomarine they were there. It was good - says T.

- Here (she points to the book) it is not a pool. It's really the sea - says E., in an attempt to convince that dolphins are not well in the Zoomarine. (Room B, jan 2019)

In Figures 4 and 5 two examples of children's drawings about the zoos are presented. Figures 6 and 7 show how children see the circus.
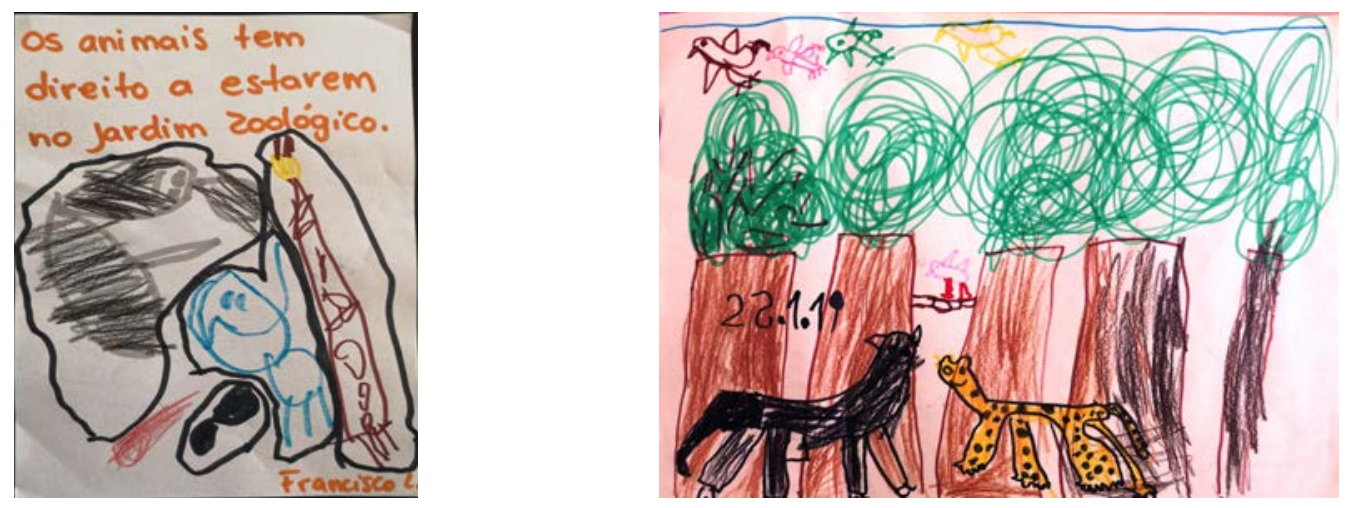

Figures 4 and 5. Two examples of children's drawings about the zoos (Room B). 

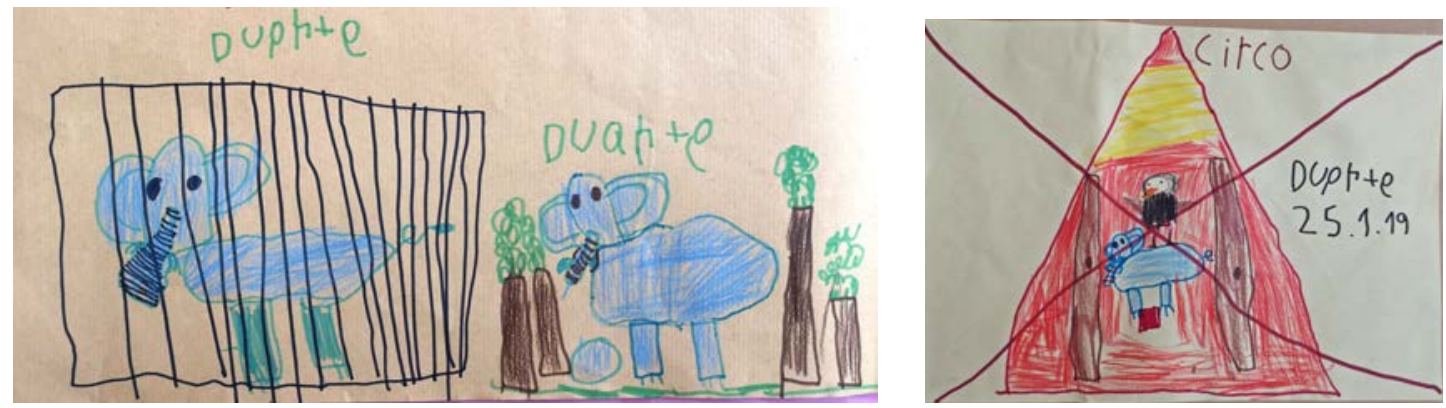

Figures 6 and 7. Animal rights seen by the children: the circus (Room C).

In room $B$ and $C$ the children identified animal rights from the knowledge that they have about their own rights as children. It is not unrelated to this fact that the discussion on children's rights is very present in the educational project of the College and in the practices and discourses of the educators.

Indeed, three categories of animal rights, when considered by the triangulation between discourses and drawings, can be identified: (i) the environmental rights (highlighting water as an essential element to animal life); (ii) the right to play (only arose in room B) informed from themselves as children, ie, as a right that children consider very important in their lives and that they transfer to animals; (iii) the right to be cared for (Table 2).

Table 2. Problematized dimensions about animal rights (room B and C).

\begin{tabular}{l|l|l}
\hline \hline \multicolumn{1}{c}{$\begin{array}{c}\text { Identified } \\
\text { Categories }\end{array}$} & \multicolumn{1}{|c}{ Room B } & \multicolumn{1}{c}{ Room C } \\
\hline $\begin{array}{l}\text { The } \\
\text { environmental } \\
\text { rights }\end{array}$ & $\begin{array}{l}\text { "Animals are entitled to eat" (MB); "Having } \\
\text { water" (ML); "Drinking water" (L.); "Taking a } \\
\text { shower" (J.); "To live" (MC); "Going into the } \\
\text { jungle" (L.); "Being in the zoo" (F.); "To have a } \\
\text { house" (V.); "Living in the jungle" (T.) }\end{array}$ & $\begin{array}{l}\text { "We have to give them food" (M.); "water" (D.); } \\
\text { "They are happier in their habitat, so we have } \\
\text { to put them there" (S.); "Animals cannot be put } \\
\text { in cages" (M.B.); "We have to give them food } \\
\text { and water (M. and D.). }\end{array}$ \\
\hline $\begin{array}{l}\text { The right to play } \\
\text { the right to be } \\
\text { cared for }\end{array}$ & $\begin{array}{l}\text { "To play with each other" (G.); "To play" (I.) } \\
\text { mothers" (A.); "To be with its mother and father" } \\
\text { (A.); "To be with their family" (M.). }\end{array}$ & $\begin{array}{l}\text {-We have to take them to the vet" (ML); "We } \\
\text { can help animals to be happy" (L.); "We have } \\
\text { to treat animals well" (G.). }\end{array}$ \\
\hline \hline
\end{tabular}

Despite they have as reference the UN Convention on the Rights of the Child ([7] ONU, 1989), children identify animal rights essentially as opportunities and desires similar to those of their lives, arising from their experiences especially in the context of their families.

\subsection{A project developed on the relationship between garbage and the way it affects animal welfare}

Only in the nursery room (room D), attended by children of 2 and 3 years, a project on whales was developed, which emerged from the reading of a book ([8] Fernández, 2017). The question that immediately arose was: do whales eat people? In their research, the children found what whales eat, but they also found photographs where they saw whales died after the ingestion of plastic.

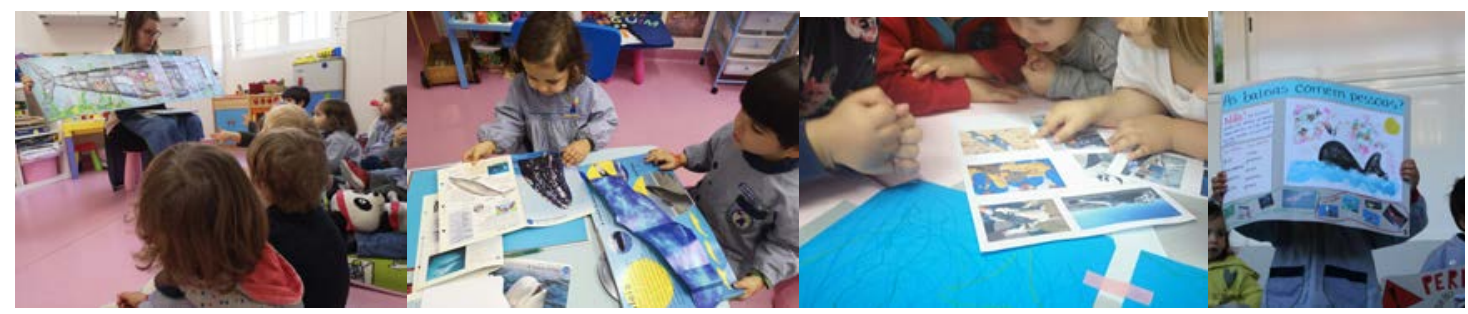

Figures 8, 9, 10 and 11. The steps of the project about whales.

The dialogue on this subject came from the observation of photographs: 
- I found in an exhibition that the sea is full of garbage! - says M.

- And what happens with so much litter in the sea, M.? - asks the educator.

- Whales die - he says to M.

- Why do they die? - asks the educator.

- They get sick and die because they eat it! [the plastic] - says M.

- When the sea is full of trash, whales can't swim! - says $P$.

- We have to clean the sea, don't we, M.? -With the fishing nets... I go with my father, S. and my mother to clean the beach - says M.D.

- People shouldn't do so much trash! - says E.

- What do you think about this, M.? - Educator.

- I think it's very, very serious! - says M.

- And then the whale died. All the garbage from the sea was bad for its belly (whale) - says $S$. (Room D, Feb. 2019)

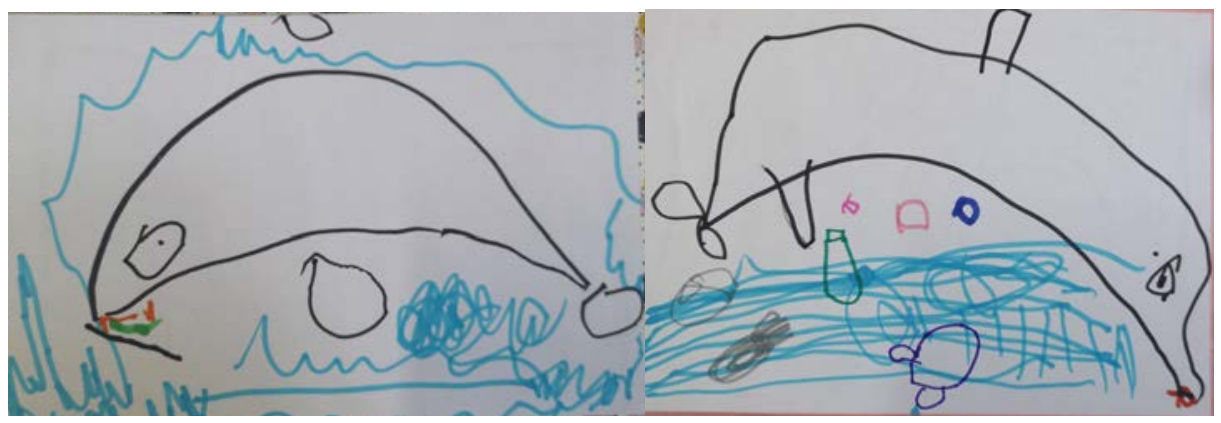

Figures 12 and 13. The whales seen by children in a sea without plastic and in a sea with plastic.

The data presented led us to better understand the reality of how young children are full social actors, competent to analyze the world in which they live and how they are aware of the problems that affect animals. The case of whales is an example that this awareness begins very early and it is real.

\section{CONCLUSIONS}

The data collected made it possible to identify certain practices developed with animals, which were sometimes problematic for children (eg. abandonment and neglect of animals, sale of animals in stores, use of animal skins for clothing and footwear) and sometimes necessary (eg. the need to invest more in promoting animal and nature rights, to think on the place of pets in their lives and to develop projects to learn more about a particular animal or situation involving them). The conflict between individual and group visions is an issue to be emphasized in the present data analysis, as well as the fact that children, especially in nursery, reveal blurring boundaries between human and non-human worlds.

Finally, it can be said that children and animals share, among other things, extreme vulnerability to climate change and its effects. Perhaps the present generation is the most at risk with regard to environmental problems and dealing with unfair situations not created by them. In this context is important to reinforce the centrality of children's actions and their social and cultural worlds to inform a childhood pedagogy, in which the educator with the children co-build a situated, participatory and citizen education.

The role of educators is thus significant because it helps children to build a universe of references, rights and social conditions in which full citizenship can occur. But for this to happen, it is necessary to effectively listen to the children. 


\section{ACKNOWLEDGEMENTS}

We would like to thank the four educators and their assistants with whom we carried out this research. This study is included in the ANIMALIS project (IPL/2018/ANIMALIS_ESELX), which is funded by the Polytechnic Institute of Lisbon, Portugal.

\section{REFERENCES}

[1] M. Cole and K. Stewart, Our Children and Other Animals. The cultural construction of humananimal relations in childhood. Farnham: Ashgate Publishing, 2014.

[2] N. Charles and C. Davies, "My Family and Other Animals: Pets as Kin", Sociological Research Online, vol. 13, no. 4, pp. 1-14, 2008.

[3] V. Policarpo, T. Monteiro, M. Truninger, A.N. Almeida, \& L, Rodrigues, "A life of their own: children, animals and sustainable development" in Changing Societies: Legacies and Challenges: Sustainability (A. Delicado, L. Sousa and N. Domingos, eds.), pp. 203- 225, Lisbon: Imprensa de Ciências Sociais, 2018.

[4] F. Ascione, Children \& Animal. Exploring the Roots of Kindess and Cruelty. West Lafayette, Indiana: Purdue University Press, 2005.

[5] B. Tipper, "A dog who I know quite well": everyday relationships between children and animals, Children's Geographies, vol. 9, no. 2, pp. 145-165, 2011.

[6] P. George, Animal Rescue, UK: PatrickGeorge Edition, 2015.

[7] ONU, Convenção dos Direitos da Criança, Available at: https://www.unicef.pt/actualidade/publicacoes/0-a-convencao-sobre-os-direitos-da-crianca/, 1989.

[8] F. Fernández. Baleia. Matosinhos: Editorial Kalandraka, 2017. 